\title{
Использование минеральной кормовой добавки для повышения переваримости и усвоения питательных веществ рациона у кур-несушек
}

Терещенко В.А., кандидат сельскохозяйственных наук, научный сотрудник

Красноярский научно-исследовательский институт животноводства - обособленное подразделение ФИЦ КНЦ СО РАН

Аннотащ,я: Представлены результаты изучения переваримости питательных веществ и баланса азота, кальция и фосфора у кур-несушек промышленного стада кросса "Хайсекс коричневый», получавших дополнительно к основному рациону минеральную кормобую добабку «Токсинон» на основе монтмориллонита 6 разных дозировках. Исследования проводились 6 условиях Красноярского края на 5 группах кур в возрасте 21 неделя по 50 голов в каждой. Продолжительность опьта состабляла 133 дня. Птице опытных групп 6 состав рациона вводили кормовую добавку «Токсинон» 6 дозировках 0,05; 0, 1 5; 0,25 и 0,35\% от массы кормосмеси. Балансовый опыт проводили на протяжении 8 дней 6 два периода (5 дней - предварительный; 3 - учетный) на 5 головах несушек из каждой группь. Установлено, что куры опытных групп превосходили аналогов контрольной группы по переваримости питательных веществ. Наиболее эрфективно питательные вещества усваивались 63 опытной группе (0,25\% «ТоксиНон»): по сравнению с контролем коэффициент переваримости сухого вещества кормосмеси 6 этой группе повысился на 2,85\%, органического вещества - на 2,96\%, сырого протеина - на 1,48\%, сырого жира - на 1,66\%, использование азота корма - на 3,52\%, кальция - на 1,5\%, фосрора - на 5,0\%, конверсия азота в яйцо - на $43,1 \%$.

Ключебые слова: куры-несушки, кормление, перебаримость питательных беществ, баланс минеральных веществ, кормовая добавка «ТоксиНон».

Введение. Концепцией долгосрочного социально-экономического развития Российской Федерации поставлена задача обеспечения потребности населения страны сельскохозяйственной продукцией и продовольствием за счет отечественного производства. В этом аспекте одна из решающих ролей отводится отрасли птицеводства [1].

Ежегодно растет производство пищевых яиц (на 1,0-1,5\%) и мяса (на 8\%) сельскохозяйственной птицы. При соблюдении правильного технологического подхода современные высокопродуктивные кроссы яичной птицы способны производить 330-340 шт. яиц в год [2].

Учитывая высокий генетический потенциал продуктивности птицы, возникает потребность непрерывного поступления в организм с кормом комплекса питательных и биологически активных веществ, способных обеспечить необходимый уровень обменной энергии в организме [3].

У птицы, в отличие от других видов сельскохозяйственных животных, по причине более интенсивного обмена веществ выше и потребность в минеральных веществах [4]. Оптимальное минеральное питание является одним из основных факторов, влияющих на качество костей и формирование скорлупы яиц у высокопродуктивных кур-несушек [5].

При недостатке макро- и микроэлементов в организме птицы возникают серьезные нарушения обмена веществ, водного обмена, нормального функционирования пищеварительной системы, значительно снижаются продуктивность и эффективность использования корма, а также естественная резистентность организма [6].

Минеральная часть рационов сельскохозяйственной птицы балансируется путем введения минеральных кормовых добавок, что дает возможность в условиях любой птицефабрики приготовить полноценную кормовую смесь, снизить заболеваемость и падеж, повысить продуктивность, сократить расходы кормов на единицу продукции, повысить эффективность ее производства [7].

Одной из таких кормовых добавок является «ТоксиНон» (OOO 
«БИОРОСТ», г. Москва), основу которой составляют минералы из группы монтмориллонита (бентонит очищенный, цеолит, высокодисперсный кремнезем) [8] тонкодисперсные глины, образующиеся в результате разложения вулканических пород и относящиеся к группе слоистых наносиликатов структурного типа с разбухающей кристаллической решеткой $[9,10]$. Они не токсичны для животных, не обладают кумулятивными свойствами и не оказывают раздражающего действия на слизистые оболочки организма [11].

Эти глинистые минералы содержат комплекс макро- и микроэлементов, необходимых животному организму, проявляют высокие связующую, адсорбционную и каталитическую активности, обладают свойствами молекулярного сита и способны фиксировать на своей поверхности желчные кислоты, кишечные газы, токсины бактерий и грибков и прочие раздражители кишечника, выводя их из организма [12].

Одним из способов определения биологической эффективности кормовых добавок в организме животных и птицы является изучение переваримости и усвоения питательных и минеральных веществ, взаимодействия их между собой в процессе всасывания, транспорта и экскреции [13].

Целью исследований было изучение влияния кормовой добавки «ТоксиНон» на переваримость питательных веществ, усвоение и баланс азота, кальция и фосфора в организме кур-несушек. В задачи исследований входило:

1. Рассчитать коэффициенты переваримости питательных веществ кормосмесей у курнесушек при скармливании разных дозировок «ТоксиНон»;

\begin{tabular}{|c|c|}
\hline Показатель & $\begin{array}{c}\text { Содержание в } 100 \text { г } \\
\text { кормосмеси, \% }\end{array}$ \\
\hline \multicolumn{2}{|l|}{ Обменная энергия: } \\
\hline ккал & 280,0 \\
\hline МДж & 1,20 \\
\hline Сырой протеин & 18,00 \\
\hline Линолевая кислота & 1,20 \\
\hline Сырая клетчатка & 6,00 \\
\hline Сырой жир & 7,0 \\
\hline Метионин & 0,43 \\
\hline Метионин+цистин & 0,75 \\
\hline Лизин & 0,85 \\
\hline Триптофран & 0,17 \\
\hline Треонин & 0,56 \\
\hline Аргинин & 1,07 \\
\hline Кальций & 3,50 \\
\hline Фосфор доступный & 0,38 \\
\hline Фосфор общий & 0,71 \\
\hline Натрий & 0,18 \\
\hline Хлор & 0,22 \\
\hline
\end{tabular}

2. Рассчитать баланс азота, кальция и фосфора у кур-несушек при скармливании разных дозировок «ТоксиНон»;

3. На основании полученных данных определить наиболее биологически эффективную дозировку скармливания «ТоксиНон» курам-несушкпм.

Материал и методика исследований. Исследования проведены в условиях ООО «Боготольская птицефабрика» Красноярского края на курах-несушках промышленного стада кросса «Хайсекс коричневый» в возрасте 21 недели, из которых по принципу аналогов сформировали пять групп (контрольную и четыре опытные) по 50 голов в каждой. Группы формировали по методике ВНИТИП [14] с учетом возраста, живой массы и общего развития. Опыт продолжался 133 дня.

В качестве основного рациона использовалась полнорационная кормосмесь «Кладка-1», предназначенная для кур в возрасте 21-40 недель и состоящая из следующих ингредиентов (\%): пшеница - 63,2; пшеничные отруби - 1,3; рыбная мука - 2,5; соевый шрот - 10,0; подсолнеч- никовый шрот - 10,0; рапсовое масло - 2,7; сода пищевая - 0,2; известняк - 8,46; монокальцийфосфат - 0,58; монохлоргидрат лизина - 0,1; соль поваренная 0,2 ; метионин кормовой - 0,14 ; холина хлорид - 0,1; витаминноминеральный премикс-0,2. Питательность используемой кормосмеси представлена в табл. 1.

Несушки контрольной группы получали только основной рацион; несушкам 1, 2, 3 и 4 опытных групп в основной рацион дополнительно вводили кормовую добавку «ТоксиНон» в количестве 0,$05 ; 0,15 ; 0,25$ и 0,35\% от массы кормосмеси соответственно. Корма задавали в сухом виде 2 раза в сутки.

Содержание кур было клеточным, в батареях КП-12лм (по 5 голов в клетке) в цехе промышленного стада, с соблюдением технологических параметров, рекомендованных для промышленных кур-несушек данного кросса. Поение производилось из ниппельных поилок, доступ к корму и воде был постоянным.

Для определения переваримости и использования птицей питательных веществ корма был 
Таблица 2. Коэффициенты переваримости питательных веществ корма у кур-несушек, \% $(M \pm m, n=5)$

\begin{tabular}{lccllll}
\multicolumn{1}{c}{ Показатель } & \multicolumn{5}{c}{ Группа } \\
\cline { 2 - 6 } & контрольная & $\mathbf{1}$ опытная & $\mathbf{2}$ опытная & $\mathbf{3}$ опытная & 4 опытная \\
Сухое вещество & $69,31 \pm 1,19$ & $70,12 \pm 0,71$ & $71,36 \pm 0,84$ & $72,16 \pm 0,88$ & $71,54 \pm 1,06$ \\
\hline $\begin{array}{l}\text { Органическое } \\
\text { вещество }\end{array}$ & $71,28 \pm 1,44$ & $71,67 \pm 1,27$ & $73,15 \pm 1,10$ & $74,24 \pm 0,64$ & $73,31 \pm 1,07$ \\
\hline Сырой протеин & $84,23 \pm 1,59$ & $84,34 \pm 1,49$ & $85,06 \pm 1,05$ & $85,71 \pm 1,23$ & $84,67 \pm 1,42$ \\
\hline Сырая клетчатка & $19,03 \pm 0,90$ & $19,22 \pm 0,78$ & $19,14 \pm 0,69$ & $19,27 \pm 0,94$ & $19,10 \pm 0,91$ \\
\hline Сырой жир & $91,75 \pm 1,16$ & $92,17 \pm 0,82$ & $92,64 \pm 1,34$ & $93,41 \pm 1,15$ & $92,87 \pm 1,13$ \\
\hline
\end{tabular}

Таблица 3. Баланс и использование азота у кур-несушек $(M \pm m, n=5)$

\section{Показатель}

Грyпna

\begin{tabular}{lccccc} 
& контрольная & 1 опытная & 2 опытная & 3 опытная & 4 опытная \\
Принято с кормом, г & $3,27 \pm 0,16$ & $3,26 \pm 0,17$ & $3,29 \pm 0,11$ & $3,29 \pm 0,08$ & $3,27 \pm 0,12$ \\
\hline $\begin{array}{l}\text { Выделено с } \\
\text { пометом, г }\end{array}$ & $1,72 \pm 0,08$ & $1,68 \pm 0,12$ & $1,56 \pm 0,10$ & $1,49 \pm 0,08$ & $1,52 \pm 0,14$ \\
\hline Выделено с яйцом, г & $0,51 \pm 0,04$ & $0,64 \pm 0,04$ & $0,68 \pm 0,07$ & $0,73 \pm 0,02^{* *}$ & $0,70 \pm 0,03^{*}$ \\
\hline Выделено всего, г & $2,23 \pm 0,06$ & $2,32 \pm 0,14$ & $2,24 \pm 0,16$ & $2,22 \pm 0,09$ & $2,22 \pm 0,16$ \\
\hline Баланс, г & $1,04 \pm 0,14$ & $0,94 \pm 0,21$ & $1,05 \pm 0,18$ & $1,07 \pm 0,10$ & $1,05 \pm 0,13$ \\
\hline $\begin{array}{l}\text { Использовано } \\
\text { от принятого, \% }\end{array}$ & $31,80 \pm 2,76$ & $29,00 \pm 5,61$ & $32,00 \pm 5,28$ & $32,52 \pm 2,76$ & $32,10 \pm 3,75$
\end{tabular}

РАЗЛИчИЯ С КОНТРОЛЕМ БЫЛИ ДОСтОвЕРНЫМИ ПРИ: *Р>0,95; **P>0,99.

проведен балансовый опыт по методике ВНИтИП [14]. С этой целью было отобрано по 5 голов птицы из каждой группы, по которым на протяжении опыта вели индивидуальный учет количества съеденного за сутки корма, его остатков, выделенного помета и снесенных яиц.

Химический состав проб кормов и помета определяли по методикам зоотехнического анализа. В исследуемых образцах корма, помета и яиц устанавливали содержание: сухого вещества - по ГОСТ 31640-2012; содержание влаги (первоначальной, гигроскопической) - по ГОСТ Р 54951-2012; общего азота и сырого протеина - по ГОСТ 32044.1-2012 методом Кьельдаля; сырой клетчатки - по ГОСТ 31675-2012 методом Геннеберга и Штомана; сырого жира по ГОСТ 32905-2014 методом С.В. Рушковского с использованием аппарата Сокслета; сырой золы - по ГОСТ 32933-2014; кальция - по ГОСТ 26570-95 трилонометрическим методом; фосфора - по ГОСТ 26657-97 вана- домолибдатным методом. Коэффициенты переваримости, балансы азота, кальция и фосфора вычисляли по общепринятым методикам.

Биометрическую обработку экспериментальных данных осуществляли методами вариационной статистики с использованием компьютерной программы «Пакет анализа для биометрической обработки зоотехнических данных» (Ефимова Л.В., 2015). Достоверность разницы между группами устанавливали по t-критерию Стьюдента. Разницу считали достоверной при Р>0,95.

Результаты исследований и их обсуждение. В табл. 2 представлены коэффициенты переваримости питательных веществ у кур-несушек при включении в их рационы кормовой добавки «ТоксиНон» в разных дозировках.

Лучшими показателями переваримости питательных веществ отличалась 3 опытная группа, у которой коэффициенты переваримости были больше, по сравнению с контрольной группой, по сухому веществу на $2,85 \%$, орга- ническому веществу - на 2,96\%, сырому протеину - на 1,48\%, сырому жиру - на 1,66\%. Что касается сырой клетчатки, то скармливание «ТоксиНон» мало отразилось на ее усвоении, коэффициенты переваримости клетчатки во всех группах были на уровне 19,03-19,27\%.

Азот используется в организме животных и птицы как пластический материал, необходимый для образования белка тела, продукции, фрерментов, гормонов, тканей и органов. Расчет баланса азота позволяет охарактеризовать состояние белкового обмена в организме, установить полноценность протеина, поступающего с кормом.

В табл. 3 представлен баланс и использование азота у курнесушек. Выделение азота с яйцом было выше в опытных группах. По сравнению с контрольной группой разница по данному показателю составила в 1 опытной группе $25,5 \%$, во 2 группе 33,3\%; в 3 группе - 43,1\% ( $>0,99)$, в 4 группе- 37,3\% (Р>0,95).

Баланс азота был положительным во всех группах кур-несушек и составлял 0,94-1,07 г. При практически одинаковом поступлении азота с кормом в организм кур-несушек у опытных групп его меньше выделялось с пометом на 2,33-13,4\% по сравнению с контролем. Несушки 3 опытной группы лучше использовали азот корма, коэффициент усвоения составил 32,52\%, что больше по сравнению с остальными группами на 0,42-3,52\%.

У кур-несушек в период яйцекладки потребность в минеральных веществах особенно высокая; когда куры начинают нестись, усвоение кальция у них увеличивается на $31,4 \%$ [15].

Баланс и использование кальция в опыте представлены в табл. 4. Баланс кальция во всех группах был положительным 
(1,46-1,56 г), что говорит о достаточном поступлении его с кормом. На образование яйца больше всего расходовалось кальция в 3 (1,69 г) и 4 (1,66 г) опытных группах. С пометом больше всего кальция выделяли куры контрольной группы (1,30 г), больше, чем в опытных группах, на 2,31-16,2\%. Использование кальция было самым высоким в 3 группе (36,0\%), выше контроля на 1,5\%.

Обмен кальция и фосфора тесно связан друг с другом. При скармливании птице рационов с отрицательным балансом кальция баланс фосфора становится также отрицательным, а избыток одного из этих элементов в рационе препятствует усвоению и задержке в организме другого [16]. При распределении фосфора в организме несушек более значительная его часть идет на отложение в депо и меньшая на образование яйца. Баланс и использование фосфора у подопытных кур-несушек представлены в табл. 5.

Баланс фосфора был положительным во всех группах и составил 0,26-0,30 г. У кур опытных групп использовалось больше фосфора на образование яйца по сравнению с контрольной группой и меньше выделялось с пометом (на 4,2-16,7\%). Необходимо отметить, что в 3 опытной группе, по сравнению с остальными, фосфор корма использовался лучше: коэффициент использования составил 38,0\%, что больше контрольной группы на 5,0\%, 1 опытной - на 3,8\%, 2 опытной - 1,29\%, 4 опытной группы на $2,6 \%$.

Более высокая переваримость и усвоение питательных веществ корма у несушек опытных групп, вероятно, связано с тем, что природные минералы, входящие в состав кормовой до-

\begin{tabular}{|c|c|c|c|c|c|}
\hline \multirow{2}{*}{ Показатель } & \multicolumn{5}{|c|}{ Группа } \\
\hline & контрольная & 1 опытная & 2 опытная & 3 опытная & 4 опытная \\
\hline Принято с кормом, г & $4,29 \pm 0,16$ & $4,30 \pm 0,16$ & $4,32 \pm 0,12$ & $4,34 \pm 0,08$ & $4,34 \pm 0,09$ \\
\hline Выделено с пометом, г & $1,30 \pm 0,09$ & $1,27 \pm 0,05$ & $1,19 \pm 0,07$ & $1,09 \pm 0,04$ & $1,18 \pm 0,04$ \\
\hline Выделено с яйцом, г & $1,51 \pm 0,07$ & $1,57 \pm 0,06$ & $1,61 \pm 0,04$ & $1,69 \pm 0,06$ & $1,66 \pm 0,05$ \\
\hline Выделено всего, г & $2,81 \pm 0,13$ & $2,84 \pm 0,07$ & $2,80 \pm 0,09$ & $2,78 \pm 0,06$ & $2,84 \pm 0,03$ \\
\hline Баланс, г & $1,48 \pm 0,23$ & $1,46 \pm 0,21$ & $1,52 \pm 0,17$ & $1,56 \pm 0,03$ & $1,50 \pm 0,07$ \\
\hline $\begin{array}{l}\text { Использовано от } \\
\text { принятого, \% }\end{array}$ & $34,50 \pm 3,78$ & $34,00 \pm 3,51$ & $35,20 \pm 3,01$ & $36,00 \pm 0,49$ & $34,50 \pm 1,02$ \\
\hline
\end{tabular}

\section{Таблица 5. Баланс и использование фосфора у кур-несушек $(\mathrm{M} \pm \mathrm{m}, \mathrm{n}=5)$}

\begin{tabular}{lccccc}
\hline \multicolumn{1}{c}{ Показатель } & \multicolumn{5}{c}{ Группа } \\
\cline { 2 - 6 } & контрольная & $\mathbf{1}$ опытная & $\mathbf{2}$ опытная & $\mathbf{3}$ опытная & $\mathbf{4}$ опытная \\
\hline Принято с кормом, г & $0,79 \pm 0,05$ & $0,79 \pm 0,04$ & $0,79 \pm 0,05$ & $0,79 \pm 0,04$ & $0,79 \pm 0,05$ \\
\hline Выделено с пометом, г & $0,48 \pm 0,01$ & $0,46 \pm 0,01$ & $0,42 \pm 0,03$ & $0,40 \pm 0,02$ & $0,44 \pm 0,02$ \\
\hline Выделено с яйцом, г & $0,05 \pm 0,01$ & $0,06 \pm 0,01$ & $0,08 \pm 0,01$ & $0,09 \pm 0,01$ & $0,07 \pm 0,01$ \\
\hline Выделено всего, г & $0,53 \pm 0,02$ & $0,52 \pm 0,01$ & $0,50 \pm 0,04$ & $0,49 \pm 0,02$ & $0,51 \pm 0,01$ \\
\hline Баланс, г & $0,26 \pm 0,07$ & $0,27 \pm 0,04$ & $0,29 \pm 0,04$ & $0,30 \pm 0,04$ & $0,28 \pm 0,06$ \\
\hline $\begin{array}{l}\text { Использовано от } \\
\text { принятого, \% }\end{array}$ & $33,00 \pm 4,48$ & $34,20 \pm 2,53$ & $36,71 \pm 3,33$ & $38,00 \pm 3,29$ & $35,40 \pm 5,10$
\end{tabular}

бавки «ТоксиНон», обладая такими свойствами как дисперсность, набухаемость, ионообменная способность, адсорбция, поверхностная активность, в желудочно-кишечном тракте птицы адсорбируют вредные вещества (тяжелые металлы, нитраты, нитриты, патогенные микроорганизмы, микотоксины, кишечные газы и др.), транспортируют ферменты и усиливают их свойства, способствуя лучшему перевариванию питательных веществ корма. Известно, что природные минералы затормаживают прохождение химуса по желудочно-кишечному тракту, за счет чего пищеварительной системой успевает усвоиться больше питательных веществ [12,17].

Заключение. Таким образом, использование разных дозировок комплексной минеральной кормовой добавки «ТоксиНон» В кормлении кур-несушек промышленного стада способствовало лучшему перевариванию и усвоению питательных и минеральных веществ в организме. Наиболее эффективное биологическое действие оказала дозировка добавки $0,25 \%$ от массы кормосмеси, скармливание которой позволило повысить коэффициенты переваримости сухого вещества кормосмеси на 2,85\%, органического вещества - на 2,96\%, сырого протеина - на 1,48\%, сырого жира - на 1,66\%, увеличить использование азота корма на 3,52\%, кальция - на 1,5\%, фосфора - на 5,0\%, конверсию азота в яйцо - на $43,1 \%$.

\section{Литература}

1. Наумова Л.И. Кормовые добавки наземного и морского генеза в рационах несушек // Птицеводство. 2017. - №12. - С. 20-22.

2. Никулин В.Н. Эффрективность применения пробиотика и соли йода в промышленном птицеводстве / В.Н. Никулин, Е.Р. Скицко // Изв. Оренбургского ГАУ. - 2019. - №5. C. 265-267.

3. Васильева Н.В. Обогащение рационов кур макро- и микроэлементами за счет биологически активных добавок из растительного сырья // Вестник Алтайского ГАУ. - 2012. - №7. С. 53-56. 
4. Эргашев Д.Д. Эффективность использования местных нетрадиционных кормов в рационе яичных кур в условиях Таджикистана: дис. ... д-ра с.-х. наук. - Душанбе, 2017. - 264 с. 5. Swiatkiewicz S. The influence of selected feed additives on mineral utilisation and bone characteristics in laying hens / S. Swiatkiewicz, A. Arczewska-Wlosek, W. Szczurek [et al.] // Ann. Anim. Sci. - 2018 . - V. 18. P. 781-793.

6. Шкаленко В.В. Эффрективность использования кормовой добавки в рецептуре комбикормов для сельскохозяйственной птицы / В.В. Шкаленко, А.К. Карапетян, А.А. Баксарова, Ю.Г. Букаева // Изв. Нижневолжского агроунив. комплекса: наука и ВПО. 2021 . - №2. - С. 298-305.

7. Большакова Л.П. Влияние природной минеральной добавки на обмен веществ и повышение естественной резистентности кур-несушек // Уч. зап. Витебской ГАВМ. - 2013. - Т. 49. №2-1. - С. 166-170.

8. Адсорбент микотоксинов «ТоксиНон»- Биорост [Электронный ресурс] / ООО «БИОРОСТ», 2021. - URL: https:// biorost.su/production/kormovye- dobavki-/toksinon/ (дата обращения: 15.08.2021).

9. Иванова О.В. Бентонитовая глина В кормлении сельскохозяйственных животных: рекомендации / О.В. Иванова, Е.А. Иванов, В.А. Терещенко [и др.]. - Красноярск: Красноярский НИИЖ ФИЦ КНЦ СО РАН, 2017. - 24 с. 10. Терещенко В.А. Эфрективность применения кормовой добавки «ТоксиНон» в кормлении ремонтного молодняка и кур-несушек: дис. ... канд. с.-х. наук. - Красноярск, 2020. - 155 с. 11. Пул ч. Нанотехнологии / Ч. Пул, Ф. Оуэнс. - М.: Техносфера, 2005. $336 \mathrm{c}$.

12. Буханов В.Д. Влияние монтмориллонит содержащей глины на организм кур-несушек при получении экологически чистых яиц / В.Д. Буханов, А.И. Везенцев, О.Н. Панькова [и др.] // Рос. вет. журнал. С.-х. животные. - 2015. - №4. - С. 8-10.

13. Шапошников А.А. Влияние новых синтетических йодсодержащих препаратов на переваримость, баланс и конверсию в яйцо минеральных веществ корма В организме кур-несушек / А.А. Шапошников, С.Д. Чернявских, Д.В. Дейнека // Науч. вед. Белгород- ского гос. ун-та. Сер. Естеств. науки. 2007. - №5. - C. 78-81.

14. Методика проведения научных и производственных исследований по кормлению сельскохозяйственной птицы. Молекулярно-генетические методы определения микрофлоры кишечника / под общ. ред. В.И. Фисинина. Сергиев Посад: ВНИТИП, 2013. - 51 с. 15. Бауман В.К. Уровень кальция, фосфора и фосфопротеина в сыворотке крови у кур во время образования скорлупы // Биологически активные кормовые добавки: науч. тр. лаб. биохимии и физиологии животных АН Латв. ССР. Рига: Зинатне, 1965. - Т. 4. - С. 57-79.

16. Бауман В.К. Кальций и фосфор. Обмен и регуляция у птиц. - Рига: Зинатне, 1968. - 372 с.

17. Дзагуров Б.А. Практическое и биологическое обоснование использования цеолитоподобных глин месторождений Центрального Предкавказья в свиноводстве и птицеводстве: автореф. дис. ... д-ра биол. наук. - Боровск, 2001. - 51 с.

\section{Для контакта с автором:}

Терещенко Вера Александровна E-mail: v.a.tereshencko@mail.ru

\title{
A Mineral Feed Additive Improving the Digestibility and Retention of Dietary Nutrients in Laying Hens
}

\author{
Tereshchenko V.A.
}

\section{Krasnoyarsk Scientific Research Institute of Animal Husbandry - Separate Division of Federal Research Center "Krasnoyarsk Science Center" of the Siberian Branch of the Russian Academy of Sciences}

\begin{abstract}
Summary: The digestibility and retention of dietary nutrients, balances of nitrogen, calcium, and phosphorus in laying hens fed different doses of montmorillonite based feed additive ToxiNon were studied on 5 treatments of cage-housed Hisex Brown layers since 21 to 40 weeks of age (50 birds per treatment). Control treatment was fed non-supplemented wheat and soybean meal based diet; similar diets for treatments 1-4 were supplemented with $0.05 ; 0.15 ; 0.25$ and $0.35 \%$ of the additive, respectively. The balance trial was performed on 5 birds per treatment during 8 days ( 5 days of preliminary period and 3 days of record period). It was found that the coefficients of digestibility and retention of dietary nutrients were generally higher in all treatments fed the additive in compare to control with the exception of digestibility of crude fiber which was similar in all treatments. The best coefficients were found in treatment 3 (fed $0.25 \%$ of the additive): higher by $2.85 \%$ in compare to control for digestibility of dry matter, by $2.96 \%$ for organic matter, by $1.48 \%$ for crude protein, by $1.66 \%$ for crude fat, by $3.52 \%$ for retention of nitrogen, by $1.5 \%$ for retention of calcium, by $5.0 \%$ for retention of phosphorus, by $43.1 \%$ for deposition of nitrogen into the eggs.
\end{abstract}

Keywords: laying hens, nutrition, digestibility of dietary nutrients, balance of mineral substances, feed additive “ToksiNon”. 